\title{
Crowds, Clouds, Politics and Aesthetics, Flipping Again
}

\author{
Esther Leslie
}

\begin{abstract}
A в STRACт This paper seeks an urban poetics under the pressures of flux, polyglot babble and the rise of technoculture. In so doing it traces the intertwinements of aesthetics and politics as they manifest over the last 150 years. Charles Baudelaire's poetry is characterised as a delirious response to the delirium of capitalist modernity, in which 'words rise up', as he puts it, but it is a also a barometer, which measures the degrees of entwinement of aesthetics and revolutionary politics in the subsequent years, for one in Walter Benjamin's interpretation in the 1930 s and in the wild translations of the poet by Sean Bonney in 2008 in the collection 'Baudelaire in English'. KEYWORDS Walter Benjamin, Charles Baudelaire, Sean Bonney, Bohemians, Utopia, avant-garde, shudder, translation
\end{abstract}

\section{Baudelaire's Mesh}

The development of a metropolitan environment and the concentration of industry forced an engagement of the polis and the arts, or, in other words, the political and the aesthetic. Gas lamps and boulevards rewrote poetry. The motorcar smudged what had been on the canvas before. Electric light illuminated the way into a new abode of culture, the cinema. Modern, capitalist urbanity brought new languages to art. It was as if the languages of the industrial capitalist polis rose up, demanded attention, entered into complex combinations with city dwellers' distracted thoughts. As Benjamin puts it, in One Way Street, writing was newly expelled, in his day, from the bed-like sheets of a book, 'a refuge in which script could lead an autonomous existence.' In the city of lights and commerce, words fizz across the skyline in the dark night, their neon alerts sparking above shops, or they stand to attention on billboards, newspapers and cinema screens. Benjamin notes of writing:

If centuries ago it began gradually to lie down, passing from the upright inscription to the manuscript resting on sloping desks before finally taking itself to bed in the printed book, it now begins just as slowly to rise again from the ground. The newspaper is read more in the vertical than in the horizontal plane, while film and advertisement force the printed word entirely into the dictatorial perpendicular. ${ }^{2}$

These vertical scripts, some endowed with the capacity to switch on and off or even to move, made the flat, standardised print of the book appear 
stagnant and archaic. The urban dweller needed to be literate in, quite literally, reading a cityscape: its signs, its words, its images, its 'blizzard of changing, colourful, conflicting letters'. Script, Benjamin notes, 'is pitilessly dragged out into the street by advertisements and subjected to the brutal heteronomies of economic chaos. ${ }^{3}$ Words are entwined with economy, with commercialism, with the insistence on consumption. And this street culture of words in the world resonated, observes Benjamin, with developments in art, where, since Mallarmé, a graphic element to script was taken up into poetics. In his 1897 poem 'Un coup de dés', Mallarmé evoked, or perhaps predicted, the graphic tensions that the advertisement would come to display. Words are strewn across the page, dynamised, the rigidity of the book's usual line broken. Font designs and sizes shift. The words scatter like snowflakes blown on the breeze. Or the page becomes like a landscape detonated by industrial developments. Pages become screenlike. Screens are pages brought to life, brought into life.

Apollinaire developed an agitated, liberated style in his Calligrammes: Poems of War and Peace, written from 1913 to $1916 .{ }^{4}$ In one poem he made the words and letters tumble like raindrops. The referents are natural - but the motivation is urban, prompted by the technologies of typography, mass production and the concocted whirlwind that is called capitalist modernity. The Futurists continued this exploration too, with Marinetti insisting on typographical innovations, to articulate the disruption of syntax, metre, punctuation in pursuit of 'lyrical intoxication', on the tail of abrupt instantaneous telegraphic communications.

Words stand up, break free, break out, it would seem. In short, words rise up. This phrase takes us back to Baudelaire, the progenitor of all this avant gardery and the institution of an aesthetics married, difficultly of course, with politics. Baudelaire does not intuit the coming of the screen and the liberated word formally, but he does activate a transformation, animated sensibility, an intoxication with the possibilities and impossibilities of city life. Words rise up .... This phrase occurs in Baudelaire's musings on intoxicated experience in 1860 or at least in Aleister Crowley's English translation of Baudelaire's Poem of Hashish from $1895 .{ }^{5}$ Describing how, under the influence of something or other, even the tawdriest wallpaper in a pub turns into a magnificent diorama and the worst ceiling paintings clothe themselves in life. Baudelaire points to a tradition of poetic transubstantiation and transmutation that had been mooted by Swedenborg and Fourier before him:

all things; the universality of beings stands up before you with a new glory unsuspected until then. The grammar, the dry grammar itself, becomes something 
like a book of 'barbarous names of evocation'. The words rise up again, clothed with flesh and bone; the noun, in its solid majesty; the adjective's transparent robe which clothes and colours it with a shining web; and the verb, archangel of motion which sets swinging the phrase. Music, that other language dear to the idle or the profound souls who seek repose by varying their work, speaks to you of yourself, and recites to you the poem of your life; it incarnates in you, and you swoon away in it. It speaks your passion, not only in a vague, ill-defined manner, as it does in your careless evenings at the opera, but in a substantial and positive manner, each movement of the rhythm marking a movement understood of your soul, each note transforming itself into Word, and the whole poem entering into your brain like a dictionary endowed with life'

For Baudelaire, words matter, words become matter. The word leaves the confines of the dry page. The word is made flesh. The word is endowed with movement and the power to transform, deform, reform. Not through godly transcendence, but through earthly, worldly, urban, profane illumination. The dictionary is endowed with life: this Baudelaire imagined - or experienced - in poetry or in poeticised life under the influence of drugs. Things, words, selves, everything takes on life. Matter is enlivened by mind. Words rise into life. Words descend into life. The page extends. The page is torn up. The page finds new life.

Baudelaire must appear in any discourse on aesthetics and politics. With whatever subtleties of spin, Baudelaire returns. Many have disinterred the French poet, in order to see how the vicissitudes of time, the passage of history, the imbrications of art, life, politics, passion, have marked themselves on his oeuvre. Baudelaire is, in Walter Benjamin's terms, 'the lyric poet of high capitalism', ${ }^{7}$ which means he is the poet who thematically and formally tracks capitalism's moves, from the perspective of someone who, as poet, intellectual, bohemian and seller of his mental labour power, is fully exposed. The translation and retranslation of Baudelaire can be seen, in this light, as a necessary act to modulate its meanings in relation to the modulating (yet never disappearing, indeed ever recurring) forms of capitalism over one hundred and sixty years. Kenneth Rexroth likewise presents Baudelaire as so mired in capitalism that he must become its recorder, its monitor and its critic:

'Baudelaire is the greatest poet of the capitalist epoch.' True or not, this statement, with its Marxist implications, is appropriate, because he is specially the poet of the society analyzed in Capital or described in The Condition of the English Working Class. His subject was the world of primitive accumulation, of the ruthless destruction of all values by the cash nexus of the new industrial and 
financial system - of bankers and their mistresses in sultry boudoirs; of the craze for diabolism, drugs, flagellation, barbarism; of gin-soaked poor dying in gutters, prostitutes dying under bridges, tubercular and syphilitic intellectuals; of the immense, incurable loneliness of the metropolis; of the birth of human self-alienation, as Marx called it - Baudelaire called it vaporization of the Ego of the Communist Manifesto; and of revolution and revolution betrayed. ${ }^{8}$

Baudelaire, as a poet of alienation, rhapsodises the loss of self. His poeticising coincides with what is perceived to be a displacement of art, a casting out of art from the securities of patronage, an exposure of art to the vicissitudes of the market. Marx offered a social analysis of the original Bohème, to which Baudelaire sometimes belonged. In 'The Eighteenth Brumaire of Louis Bonaparte' (1852), he placed nineteenth century Parisian bohemians, art hacks and art lovers, in the company of petty criminals and political conspirators. From about 1852, with the crushing of the 1848 ers' revolutionary movement complete, the victorious section of the bourgeoisie, supportive of 'a party of order', sought to take its 'cause' away from the most articulate artists. They called upon Napoleon III:

to destroy their speaking and writing segment, their politicians and literati, so that they might confidently pursue their private affairs under the protection of a strong and untrammeled government. ${ }^{9}$

Artists scurry to the margins, representing no-one clearly, and certainly not officialdom or a heroic ascendant class. It is in such a fraught atmosphere that Baudelaire operates, scuttling between factions, susceptible to influences, ideologically wed to no one force, spurning conformity in all its guises, lurching between destructive nihilism and constructive re-ordering. Baudelaire is a modern anti-hero. Like the conspirateurs, he is disaffected, but he is also dependent on the money-suppliers, the patrons, publishers and the press. He is a provocateur. In Belgium, Baudelaire was regarded as a French police spy. In France he oscillates between backing the revolution of 1848 and supporting clerical reaction. He is like an anti-citizen of the lumpen world, 'social scum', a passively rotting mass of the lowest levels of the old society, flung into action here and there by proletarian revolution, but always ready to sell itself to reactionary intrigues. For Walter Benjamin, Baudelaire is a 'secret agent' in another sense. The class's fault lines run through him, for he is 'an agent of the secret discontent of his class with its own rule'. ${ }^{10}$ For him, the revolt is all, even the revolt against the revolt, hence his swift shifts of allegiance. And yet all this is just a simulation of action. Baudelaire - and through him, the avant-garde - has a complex relationship 
to politics. Their aesthetics embraces the political, rejects it, transforms it, negates it, spurns it, cannot avoid it. The shock, frustration, anger, disappointment and resignation of Second Empire France are registered, insists Walter Benjamin, in the very rhythms and diction of Baudelaire's poetry. The words, the rhythms absorb the tensions of a new age. As poems they record, transform and rise above the tensions.

Out of all this, emerges a variety of alliances between politics and aesthetics. The first is gestured at already: urban-technological rhythm marks itself on the poetic corpus, makes the poetic word animate, breaks it from the page or, alternatively, its rhythms break into the page and bring it to life. Another encounter of aesthetics and politics puts the emphasis on creative work as a realm of transformation, of possibility, a utopian site that anticipates future social relations. This is present in dreamlike form in Baudelaire's search for new perspectives, be it those of the drugged experimenter, the drunk or the child - and the translation to which Baudelaire was committed and subjected is perhaps another mode of transformation. There is another version of it that is more concretely attuned to social transformation, understood as that which can even remake that which goes by the name of nature or habit.

\section{The Techno-Utopian Accord of Aesthetics and Politics}

In the initially expansive conditions of the revolutionizing Soviet Union, the young theorist Nikolai Tarabukin, in March 1922, wrote a pamphlet titled 'From the Easel to the Machine'. He dedicated it to 'All the people of the future'. Such was the expanse of post-revolutionary Soviet aesthetics: they would speak across time. A movement from past to present to future was tracked in the move from easel to machine, and from the still stunted humanity - that included such dilettantes as Constructivists - to a future humankind who would be artist-engineers, or better, something new, a name yet unacknowledged, once art has been 'liberated' from literary and illusionist traits, from the fetters of 'naturalistic tendencies'. Tarabukin announces the way out of what he and others diagnosed as a 'crisis of art'. Established forms are dissolved by art forms and processes that correspond to the needs of the everyday. They are superseded by the functional and practically necessary forms of an art that does not reproduce the external world nor adorn it in decorative packaging. Art and everyday life meld. This is not to be seen as the 'death' of art, but rather a 'further evolution of its forms'. Art is released from the cages of the museum to operate in life itself. This Productivist apocalyptic demand boldly expresses a new ground for politics and art, or folded one into the other, or sublated both, segueing 
them with life, or work, or the everyday. The better-world-boosters such as Malevich, Tatlin, Rodchenko, Popova, Rozanova, Matiushin and El Lissitzky, conceived their art in terms of blueprints for the future. This means less that art re-presents tangible images of the future but rather that it institutes modes of non-commodified production or test-runs transformed social relations whereby art segues into life, transmuting both. In the case of the Soviet artists there was some justification, for they operated in times of transformation, not least times of transformation for art, which emerged from the galleries and museums, dropped its preoccupation with individualistic artists, instead organising itself into agit-prop groupings, grasping towards new technological forms of expression, and rushing forward to meet its audience on newly defined terms.

This tremble, this fury, this bustle, perhaps itself as much a political overturning as an emulation of the frantic rhythms of city life, an encounter with the industrial, urban, mass, is one accord between the aesthetic and the political. Of course there is another powerful intercourse, the one dead set against the Benjaminian embrace of the technological and the urban. It rests on negation. Its aesthetic is black and barely there. Aesthetics and politics meet in a refusal. In Baudelaire's malady and in his assault on lyricism and bourgeois life we see something of this. In Adorno's Minima Moralia: Reflections From a Damaged Life, there is an entry titled 'Sur l'eau'. Here Adorno speculates on utopias, ones that are released from the needs of production, turned into an end in itself. Adorno's specific target of attack is the socialist utopias of the nineteenth century, where life is posited as rich and bustling, on the basis of technological expansion and its colonisation of the lifeworld. In such a utopia the collective undergoes a 'blind fury of activity'. In his usual contrary fashion, Adorno, of course, turns all this upside-down and renders another alignment between aesthetics and politics. He wishes to imagine a future utopia as emancipated from present mores. His utopia is one that does not conceive the forces of production as the sum total of human endeavour. Perhaps, he muses, humans will grow tired of the idea of development and expansion. Perhaps they will collectively decide to leave all sorts of possibilities unexplored, 'instead of storming under a confused compulsion to the conquest of strange stars'. Once deprivation is no longer an issue, it will become clear how all the propositions designed to eliminate want only increase it on a larger scale for many. What is then utopia for Adorno? It is, instead, a sliver of experience, a moment of rest and contemplation. Rien faire comme une bête, lying on water and looking peacefully at the sky, 'being, nothing else, without any further definition and fulfilment'. This is fulfilled utopia standing in 
the place of process, act and satisfaction. Utopia is a luxurious indolence, an everlasting peace. Art holds a place for languid utopia and, in its mode of composition, indicates a hint of what might be non-alienated labour, which is no labour at all, in a sense. The glimpse of the utopia proper to the idle beast suggests that the time proper to utopia is a primordial one. It is also a primitivism that inheres in art, or our response to it, for Adorno. Art evokes our one last glimpse of otherness that in former times would have made us shudder. Once something we might call aesthetic experience evoked terror. Adorno equates aesthetic experience with the evocation of a shudder. 'Ultimately', he notes, aesthetic comportment is to be defined as the capacity to shudder, as if goose bumps were the first aesthetic image.' ${ }^{11}$ The goose bump is the transformation of smooth skin into bumpy surface, through being touched, figuratively. 'You create a new shudder', wrote Victor Hugo to Baudelaire in 1859. In Aesthetic Theory, Adorno quotes Hugo's comment and introduces shudder as that which can break the spell of reification - '... life in the subject is nothing but what shudders ... Consciousness without shudder is reified consciousness'. For Adorno, the shudder is a primal component of experience, emerging just as humans began to conceptualise the world and differentiate themselves from amorphous nature. It is a sentiment continued in the phrase 'they shudder to think'. The shudder indexes terror, a register of the uneasiness induced by strangeness. At the same time, though, the shudder is a manifestation of wonder and a recognition of the possibility of anti-egoistic human interrelationships with other or with non-human beings. Shudder is a signal of the possibility of self-transformation. Its twitching indicates a capacity for mimesis, a sympathetic connection between self and otherness. ${ }^{12}$ The shudder, then, is on the cusp. It inaugurates the attempt to master nature, to overcome all that is different. But it also marks the point of an afterwards that might still - if only bodily, unconsciously, involuntarily - remember what it was like to once be touched by something different, something unassimilated and unassimilatable. The effort to subjugate, or tame, nature eventually threatens to eradicate the shudder. All that is different, nature's otherness, is subsumed in rationality, in industry, in synthetics, in banality. The shudder threatens to dissipate and with it any possibility of true experience. At moments in our 'damaged lives', as Adorno terms them in the subtitle to Minima Moralia, particularly moments of true aesthetic encounter, it is still possible for genuine experience to occur, and when it does, it does so with a shudder, which is, simultaneously, a recognition of the deadening nature of a dull universal fungability and a self-liquidating encounter with the non-identical, the radically different. The self, for a few moments, 
recognises itself as semblance. The I, 'that internal agent of repression' is shattered by art, which is, at that moment, 'the historical voice of repressed nature'. ${ }^{13}$ Art can utter the unutterable through the medium of the complete negativity of the world, through evoking terror. ${ }^{14}$ Art holds a place for utopia, though it cannot represent it, instead figuring this future state negatively. This is Adorno's accord or discord of aesthetics and politics. Its aesthetic-political figuration takes place only in various shades of refusal, negation, rejection.

\section{Utopia Here}

What if the projected never world of utopia were brought into view, animated and palpable? What if the liquidation of the self crystallised into a new self, turned inside out, driven by dreams. What of the utopian, a Romantic veneration of the fairytale and the perspective of the child? This accord of aesthetics and politics is something akin to Novalis' 'qualitative potentializing' of everyday life. At the close of a radio lecture on Berlin toys from 1930, Walter Benjamin invokes the Romantic author Clemens Brentano. ${ }^{15}$ Benjamin tells of how he has been seeking toys from his past in the city shops. In the course of this, he has been reminded of ships in bottles, and not just ships, but crucifixions and mountains, made of hardened wax and caught within glass. These look to him like the magical land of Vadutz, which Brentano describes in the introduction to his fairy tale 'Gockel, Hinkel and Gackeleia' from 1838. Brentano writes: 'All the magical mountain ranges of the world of stories, fables and fairy tales, Himmelaya, Meru, Albordi, Kaf, Ida, Olympus and the glass mountain lay for me in the little country of Vadutz.' Vadutz is the imaginary place where Brentano placed all the fantastical nature that he loved. Vadutz is imagination. Vadutz is a land where nature is re-imagined just in the way Ernst Bloch saw it refunctioned in folk and fairy tales, becoming elsewise to itself, turning into its opposite in a display of endless potentiality.

Vadutz: a magical, fuzzy place of waiting and longing. This is a world in which nature is remoulded, but according to imagination and social prompts from a world that must one day and in some form become actual. This is nature animated, more like that world where technology and magic are one, as cartoons, modernised versions of the folk and fairy tale world, well understood in their presentation of overlively objects, or cows that turn into musical boxes, skirts that become parachutes when needed, or church steeples that crunch themselves up in order that the crazy plane can avoid crashing into it with Mickey and Minnie Mouse on board. Distortions make the world pliable, produce of it analogies or similarities. 
Benjamin tells an anecdote from his childhood in which it is language that slips and slithers, twists, and in so doing, transposes its parts into him.

on one occasion, chance willed that Kupferstichen [copperplate engravings] were discussed in my presence. The next day, I stuck my head out from under a chair; that was a Kopf-verstich [a head stick-out]. If, in this way, I distorted both myself and the word, I did only what I had to do to gain a foothold in life. Early on, I learned to disguise myself in words (Worte), which really were clouds (Wolken). The gift of perceiving similarities is, in fact, nothing but a weak remnant of the old compulsion to become similar and to behave mimetically. ${ }^{16}$

The lesson of childhood is that creative and active transformation of the world, the word and oneself is the only way of making a livable life. These correspondences, similarities, analogies reanimate something very old, a primitive way of being for humankind. The child recapitulates the history of the species. The Benjamin-child finds words to be a special site of this mutability:

In me, however, this compulsion acted through words. Not those that made me similar to models of good breeding, but those that made me similar to dwelling places, furniture, clothes. ${ }^{17}$

A boy as a table or curtain. A pair of trousers with personality. An animated house. This takes up something of Adorno's sense of the liquidation of the self in an act of encounter. But it is more creative in its accent on potentiality, on transformability. The refusal becomes playful. Indeed, it is no surprise that Benjamin cherished the world of animation, that he saw film as properly the realm of Mickey Mouse and a counter-physics expressed in montage, trick effects, nonlinearity and the absurdities of the plotlines. In this shattered, shuddered realm, we find not the Productivist utopia of art, nor is it Adorno's negative utopia, but rather the work of art as a potentiality, that takes shape technically, in some sense, and always in relation to a mediated nature. Created are instances of what Benjamin calls different nature because it is different to ours, but not distinct from. Different nature - as mediated in the photograph or the film or the cartoon or the montage - conveys a nature that is shattered and recombined. It is a rendering of space and time and matter annihilated, recomposed. It is a parallel world. It is our nature processed through concept, imagination, history, politics, technology, urbanity - humanity. It is our nature returned back to us through our own mediation. As the expressionist director Paul Wegener put it, in 1916, in a lecture on the new abstract cinema, the aim, for him and his co-explorers, was: 
Crowds, Clouds, Politics and Aesthetics, Flipping Again

a kind of cinema which would use nothing but moving surfaces, against which there would impinge events that would still participate in the natural world but transcend the lines and volumes of the natural. ${ }^{18}$

Animation, used here in its widest sense, does not depict anti-nature, but 'other nature', which might indeed be the non-instrumentalised nature that we would commune with, were we not dangerously far along the route to ecological disaster. Art comes to be the experimental place in which nature can be left behind, or where its rules can be bent. Such disturbance of the natural is an opening onto the political, or onto policy as a realm of reflection on what is and what could be.

\section{Aesthetics and Politics Today: Back to the Start}

In today's world, no one would disagree that politics is aestheticised, a matter of spectacle. Conversely, who would quibble that aesthetics is politicised, in the sense that all that is cultural has become contestable, either by aestheticians who cannot shake off a sense of art's enhanced or decreased value in its proximity to the political, to political claims, social efficacy, markets. The existence of the culture industry producing 'mass' and 'elite' art is a given. To be part of the culture industry is for art or culture to be understood in relation to markets - in relation to segmented audiences, to profits and returns, to publicity, to policy. Financial models, questions of access, the high price of art, the return on the value of investments, all this is part of our current mode of being political. In our context, it is implausible to be enthusiastic about the urban rhythms, about new technologies that usher in the possibility of new social relations. Recuperation is too rampant. Refusal of the aesthetic, perhaps, finds now some sort of articulation in the thesis of 'dark matter', the idea that most artistic production takes places out of sight, uncredited, almost in secret, beneath the view of the art markets. But to view such practice that is not marketable in this way is also a desperate consolation for the refusés, or rejects, who would in most cases rather be at the master's table. And as for the positing of another nature. The transformative energies of animation, the capacities of art for reshaping, have a different resonance in a liquid crystal epoch of screens on which little takes place that is not constructed, reformed, in some way. Walter Benjamin wrote about the word rising up. The page becomes an upright medium. As such it emulates or opens the way to the advertisement, and to the animate surface that is the screen. In our age, in the cities, swirling, chaotic writing, words screaming from billboards, moving vehicles, LED screens, demand and 
never really find adequate enough attention. It may be that our reading, day to day, in the cityscape, is more like traipsing through a blizzard of words that jostle for our attention, while we absorb them more dreamily, inattentively. But they do seem currently to have the upper hand. If Benjamin saw them mobilise into uprightness, now they swarm, chasing us, catching up with us wherever we are, glimmering from those little handheld gadgets that people carry. Beeping, squawking, demanding attention. A flurry of messages keeping us on message - on line, on a line, hooked, lined and sunk. Our attention is commanded. What to do? Return to the beginning. Each mode of articulating aesthetics and politics might come to seem inadequate in the face of the culture industry, the markets of art, the mastery over nature - through the computer's emulation and consequent vanquishing of over the shaping, esemplastic power of nature mediated through imagination. Start again then. Baudelaire returns, but necessary is a triple exertion on the aesthetic-political field. I will end by looking at how one small effort at artistic practice mobilises all of the aesthetic-political modes incubated in Baudelaire's lyric, tripled in strength, as if to squeeze more significance from them. This example combines in one artistic assault an absorption in city rhythms and exigencies, a refusal of marketable and conventional aesthetic formats, and a commitment to an aesthetic of transformation, of super-mobility and linguistic uprising.

Sean Bonney's cycle of poems from 2008, 'Baudelaire in English', conveys Baudelaire into the present. It samples the original historical energy of the poems (as does any montage aesthetic that valorises the specificity and historical sedimentations of the fragments it deploys) and releases that energy into the frenzy of the now. Walter Benjamin translated some poems by Baudelaire. He reflected on the process of translation in the preface to the collection from 1921, called 'The Task of the Translator.'19 Here he explained what a translation communicated: not the imparting of information, but something that developed from the original, as an echo, emerging in its 'afterlife', its renewal through its existence in another language, another epoch. His is, then, not a theory of translation as nailing the meanings accurately, but rather something more supple and subtle, porous to context, open to historical change. Words as mutable, absorbent, bendable, though not without some sort of historical fidelity. Attention is paid, then, to particularity, to historical resonance, rather than standing to attention before the military tribunal of accurate deciphering, the quasi-religious adherence to 'faithful' conversion. 


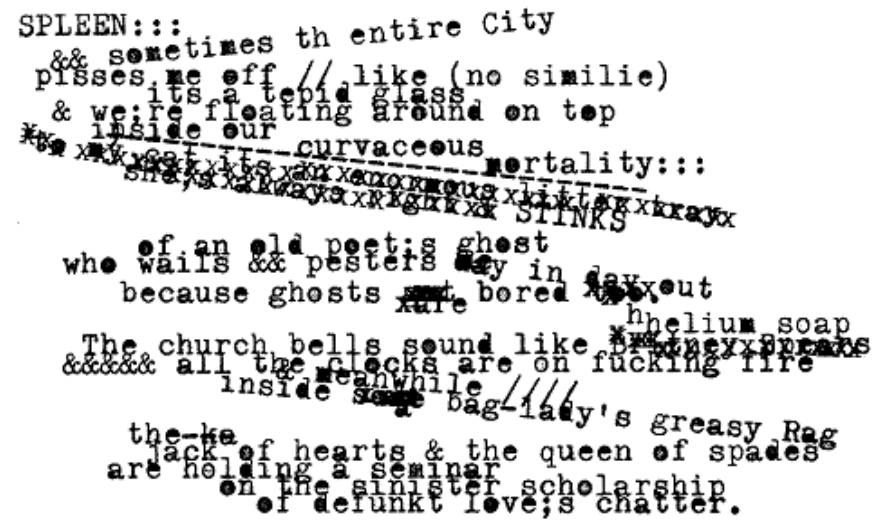

For Bonney, these poems cannot be rendered in the traditional format of lines and stanzas. They are graphic, concrete. The words in their broad translation and in their spatial dislocations on the page rise up, are squashed down, are involved in a variety of battles over meaningfulness and placement. It is as if the words are animated, pliable, slippery. The words scuttled like typewritten ants broke free from the page. They slant like psychotic print outs. Text emoticons are shattered into scraps. Any lingering languorousness in Baudelaire's mournful glance across the city is expunged. The city appears but as an even more hyped up place of language contortions, violent clashes, word manglings, battles over space and order. The language used is not as high-flown as Baudelaire's. It is banalised. It draws on the languages of the streets, and avoids poetic transcendence. For example, the sentiment from Baudelaire, elsewhere rendered in translation as 'When the low, heavy sky weighs like a lid / On the groaning spirit' (William Aggeler) or 'When the low, heavy sky weighs like the giant lid / Of a great pot upon the spirit crushed by care,' (Edna St. Vincent Millay), is in Bonney reduced and de-poeticised: ' $\& \&$ sometimes th entire City / pisses me off'. Then, no simile is found to complete the image and the fact of this lack is made explicit: 'like (no simile)'. Language is severely doubted - a line is translated, but crossed out and only the word STINKS is legible. It is reduced but it is also stretched. Baudelaire's idea of bored ghosts emerges not where it is in his poem, in the second line, but rather in a new stanza. The poem has been dissected, cut apart and the insides plummet down the page. Then suddenly we are at the bells of Baudelaire's fourth stanza, and, after that moment of touching directly on the poem again, it takes off somewhere else, with only the slightest echo of Baudelaire's obstinately complaining bells in 'defunkt love;s chatter'. 


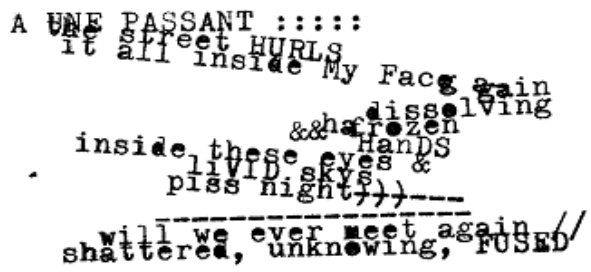

The street hurls it all inside my face. This is a translation of 'La rue assourdissante autour de moi hurlait'. In Baudelaire, a certain separation remains: the deafening streets roared out around me. For Bonney, the street is an experience of pressure. It hurls the poetic content at the poet, who hurls it back.

Or Compare Edna St. Vincent Millay and George Dillon's 1936 version of 'Reve parisien' and Bonney's from 2008:

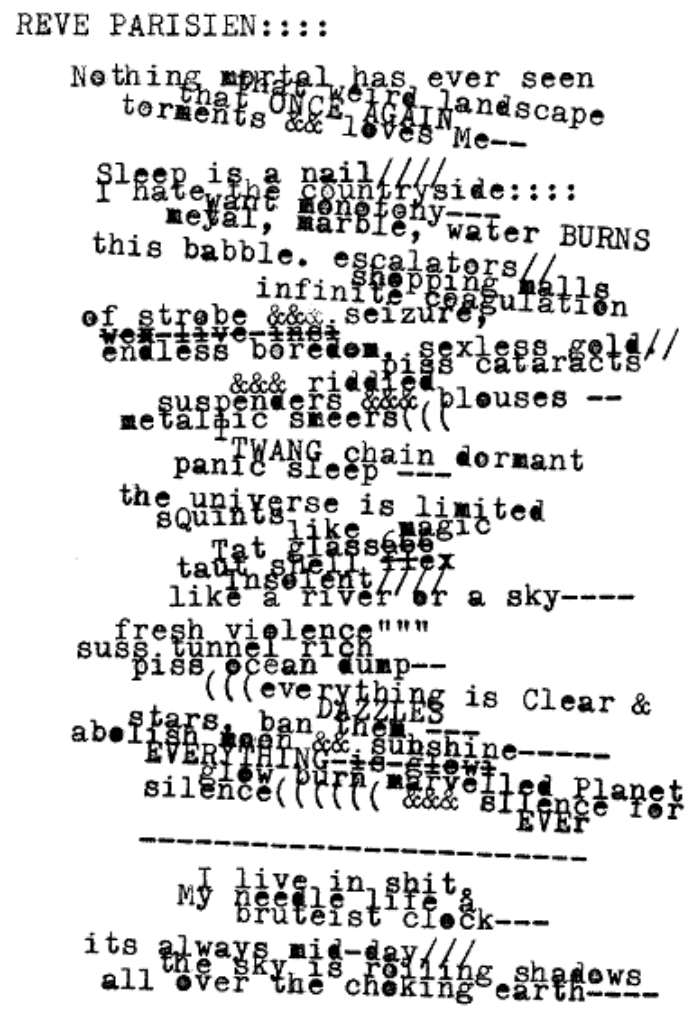


Crowds, Clouds, Politics and Aesthetics, Flipping Again

Edna St. Vincent Millay’s and George Dillon's final lines are rendered as:

I woke; my mind was bright with flame;

I saw the cheap and sordid hole

I live in, and my cares all came

Burrowing back into my soul.

Brutally the twelve strokes of noon

Against my naked ear were hurled;

And a gray sky was drizzling down

Upon this sad, lethargic world.

Bonney's final stanza:

I live in shit

MY needle life a

bruteist clock---

its always mid-day///

the sky is rolling shadows

all over the choking earth----

The sentiment is degraded, from 'cheap and sordid hole' to 'I live in shit'. 'MY needle life': drugs enter these homes as shitholes, drug dens, which then diverts the metaphor into that of the drugs wearing off and the cares returning to the soul, or rather the body. The motifs that are embedded in Baudelaire in chains of words are placed directly, so the distancing reference to time - the chiming clock with its funereal accents - becomes simply a clock. The cluttered and languid language of Baudelaire, deployed then as revolt against speed up, register of emergent temporalities, reduces to shock, the spluttered, paratactic mutterings of someone stranded after the new era, and hyped up on anger's energy. The experience is extended - it is always mid-day - not a singular poetic glimpse, but a universal, and so more horrible, more trapped. And the earth is no longer this passive thing, this melancholic object of contemplation, a poetic object, rather it is choking. The earth, which is our body, chokes for us and with us. It is another version of the old pathetic fallacy, but it is one that figures in a contemporary imagination of ecological crisis, as greenhouse gases choke it and us and the boulevard gives way to escalators and shopping malls.

One by one Bonney retranslates Baudelaire's poetry into splenetic anti-verse. The question of 'fidelity' is posed differently. There is no careful and scholarly attention to meaning in the narrow sense, rather 
faithfulness to meaning in another sense. The viciousness of the original segues with the contingent urgency of the moment. Language is torn. French is mockingly translated and the English into which the poems are conveyed is one that can only splutter its senses out, on the edge of inarticulacy. As the final line of 'A Une Passante' puts it: 'shattered, unknowing, FUSED'. This is language damaged, language as damage, language as register of damage. It is a language that hopes to have ingested terror, a terror that might once have been a component of art, but is now absent. Perhaps this takes us towards art as negation of itself, as refusal, as register of horror, such as Adorno prized. Bonney rips up something that has sedimented into unquestioned value. The lines in Bonney's Baudelaire poems stamp on each other. They slant and clash on the page. Unpronounceable characters - brackets and commas, asterisks and carets - force their way into places they should not be. Some words are made barely legible by overtyping. The whole looks like a tumbling pile of words and blackness. It dissuades from a passive, contemplative scanning, and yet it impedes alert reading too. This shake up of poetry stretches lyric form just as Baudelaire in his day stretched lyric form to incorporate new contents, adulterating poetry, in order to make it again, but as something else. There is transformation, translatability, transportation at work here.

Sometimes Bonney takes the language of the enemy - Tony Blair's speeches for one - and slashes it into part meanings, which release the violent truths masked within hypocritical language. Ripping the speech up, tearing speech itself up, exposes the violence that backs the seemingly innocuous articulation. The words are mangled such that they can only be spat or shot out on the edge of comprehensibility, but traces of their ideological force, countered in an almost homeopathic act of debarbing, are still audible, if only because of the predictability of political rhetoric. Those political slogans returned precisely to their origin: 1513 is the first attested use of slogan, the 'battle cry', from the Gaelic sluagh-ghairm, the cry of a war-mongering horde. Bonney turns back to Baudelaire, as initiator of a critical modernity, in which the demands of the new now are negotiated in the poem as damage and potential of modernity's impulse.

The Commons, a subsequent cycle, appeared over several months in segments on Abandoned Buildings. ${ }^{20}$ The title indicates something of the political and social concern that motivates the work. The notion of the Commons has various echoes: the areas of common land from which the populace have been dispossessed; the elements of the environment that 
could enjoyed by all, because they evade commodification - the rivers, atmosphere, beaches, forests; the cultural heritage, a social construction consisting of language, social bonds, affects, ideas, all that which derives from the folk and that from the canon, which has insinuated itself into our memories, and which, through the internet, might be easily and equitably accessed; the House of Commons, that is anything but; the commoners kept firmly outside, also known as the common people. The common has its poetic provenance. In the preface to his Lyrical Ballads, Wordsworth notes how his

principal object proposed in these Poems was to choose incidents and situations from common life, and to relate or describe them throughout, as far as possible, in a selection of language really used by men, and, at the same time, to throw over them a certain colouring of imagination, whereby ordinary things should be presented to the mind in an unusual aspect. ${ }^{21}$

In the miasma of the French Revolution, Wordsworth infiltrates vernacular language and ways of the common into the realm of poetry. Bonney's evocation of the commons continues this work in a way appropriate for today, after more than a hundred years of industrialisation and now that the term, the commons, has become associated with a politics of collectivity. To refer to the commons is to indicate a desire for sharing in (and defending the existence and expansion of) public goods, of things held in common and belonging to no-one. It has found theoretical formation especially through the thought of Michael Hardt and Antonio Negri. 22 'The Commons' works on this common property by appropriating lines and themes from folk songs, from common materials, which are then spliced together with popular cultural references alongside ejaculations of anger, 'in splintered oblique English', in landscapes populated by 'exhausted shoppers', zombies, 'used opinions': 'Unaroused by official culture / history has been stashed / below a system of false brains'. Language is corrupted - 'prepared vocab' - and places limits on what can be thought and known: 'but anyway, inside this language / there is no word for sky'. A return, through brokenness, to expression is under way, as part lines return, gather new meaning, new contexts. The scraps of common history, of solidarity, are shown to be fragmented by bourgeois relations of ownership: 'a businessman's / girdle round the earth / is a dream deferred'. Yet these struggle, within the poem, to recombine with each other or to engage in their own war on simplified meanings, on surface truths. 
Of gorgeous magnetic fiends

even the memory is blocked:

history's shadow stalks us

call it the net of

the idea is simple

\& permanently freakish:

to live outside of servitude

the confidence \& cowardice

of those who force us

into fiction, difficult \& locked.

But the scorn we feel

BANG

night of the living dead

all else is annoyance $\&$ avarice

Our present is hell, the zombie realm of the living dead. To live freely an idea so simple and yet so impossible, a fantasm of freaks and lunatics. Only in our fictions, our Romero movies, can we take our revenge on those who force us to live this half-life, who let us shudder in the cinemas, only so we might feel a semblance of life that we cannot live outside. History accompanies us, as a shadow, there and not there.

Into the mix of the poem too are chucked fragments from the Angry Brigade Communiqués and repeated references to 'the british anarchist movement': 'its scales \& documents / splintered under a false full moon / embroidered over with burning gold / not.' 'We don't know who they are / not', states the poem, in reference to the most famous sentiment from the Angry Brigade's writings: 'We are not in a position to say whether any one person is or isn't a member of the Brigade. All we say is: the Brigade is everywhere'. The line 'He is the man or woman / sitting beside you' directly references a line in the Angry Brigade's Communiqué 9: 'The $\mathrm{AB}$ is the man or woman sitting next to you. They have guns in their pockets and anger in their minds.'

One stanza doubts poetry itself at the same time as it reaffirms it, but in this new, battered form.

recent irruptions of unmeaning

in Kabul etc, where

we have never been,

have made poetry obsolete:

but still my red shoes

would go dancing, 
Crowds, Clouds, Politics and Aesthetics, Flipping Again

tho not a soul would look out

from the curfew, the

cosmetics counter,

everyone knows it,

a sentimental space, purely

some kind of folk song, to

give up all love,

the city hurts when its broken

Poetry itself, it would seem, needs to be overcome, because of its uselessness in relation to the overwhelming senselessness of war, specifically one in Afghanistan that is the longest in US history. Poetry might even be complicit (a legitimating force): 'the dreadful cries of murdered men, / inside poetry'. Or poetry is not even seen, or is thought to be already known, a ditty half-remembered from childhood, not a language of political argument or political practice. Everything rigidifies. The mind is on the point of being entirely absorbed: 'but still my red shoes / would go dancing, / tho not a soul would look out from the curfew'. To keep producing poetry like that produced before and during the committing of inhumane atrocities perpetuates the barbarism that masquerades as culture and renders all that emerges under the label creative production reified and unassailable, seemingly a special realm.

Against 'self-satisfied contemplation', in favour of the scream, Bonney writes what he terms a 'revolutionary poetics'. Abandoned Buildings publicized a reading list for a 'Revolutionary Poetics' on 21 March 2010.

chapters on Pythagoras and Philolaus // Kirk et al THE PRESOCRATIC PHILOSOHPERS (2nd Ed)

ANDREA BRADY /// WILDFIRE: A VERSE ESSAY ON OBSCURITY AND ILLUMINATION

Brecht: German Satires

MAYAKOVSKY // RIMBAUD at the same time passages on Circulation \& Production Time, GRUNDRISSE (Marx, yeh)

Amiri Baraka // Blues People / Black Music / The Dead Lecturer Poems by CECIL TAYLOR / ANNA MENDELSSOHN

Luigi Nono: como una ola de fuerza y luz // non consumiamo marx BLACK FIRE: 1968. Edited by Amiri Baraka \& Larry Neal

William Rowe: The Earth Has Been Destroyed Lenin's Notebooks on Heraclitus \& Hegel's History of Philosophy (passages on musical tones, electrons) rockabilly etc // Iancu Dumitrescu // Bud Powell 
Walter Benjamin: Epistemo-Critical Prologue ORIGIN OF GERMAN

TRAGIC DRAMA

Pasolini: Heretical Empiricism

PAUL CELAN / CESAR VALLEJO at the same time

CLR James: The Black Jacobins

Everybody Talks About the Weather ... We Don't: ULRIKE MEINHOFF

It is a mélange of political theory, radical philosophy, experimental music, pop music, and poetry - a manifesto by association and collage, a lineage of materialist thought from the Pre-Socratics to Ulrike Meinhof. It acknowledges debts to the (artistic) avant garde and the (political) vanguard, and would endeavour to bring them together. This is a re-splicing of something that has fallen apart. Like Punk and like Surrealism, the language of Bonney's bouleversed Baudelaire and his paean to the Commons cannot shake off a simultaneous attraction and repulsion towards the streets, attraction and repulsion in relation to the vulgar commercial contents that line them, the violence that is more or less openly manifest on them. The language and the mode of address is enraged and engaged. Yet the anger and the desire to act cannot mesh coherently, because that coherence would be too complicit with corrupted thinking. It can, however, be a common resource, a splintered reservoir of memory, of antispectacular citations of old revolts, of discussions amongst ourselves of old failures. The graphic nature of Bonney's Baudelaire poems impedes their easy reading, their untrammelled communicative ability, because their so obvious truths find it hard to make a passage into the world. It is as if all is turned backwards or on its head, toppled over or disarranged, in order to be all the truer. Their visual and graphic form suggests something splattered on the pavement, words that rose up in advertising and avant garde poetry smashed back down to the ground, to the common ground, in order to rally the troops, our troops, to combat a terror that is outside us, but in every syllable of our language, every grain of our word and world. Shattering linguistic coherence, writing anti-writing, exploding the even line on the page, making anti-sense, upping the ante, allows, at least, a glimpse of parallel - potential - words and worlds that might be yet re-articulated.

\section{Notes}

1. Walter Benjamin, 'One-Way Street', in Selected Writings, vol. 1 (Cambridge, MA: Harvard University Press, 1999), 456. 
Crowds, Clouds, Politics and Aesthetics, Flipping Again

2. Walter Benjamin, 'One-Way Street', in Selected Writings, vol. 1 (Cambridge, MA: Harvard University Press, 1999), 456.

3. Walter Benjamin, Selected Writings, vol. 1 (Cambridge, MA: Harvard University Press, 1999), 456.

4. See Christopher Butler, Early Modernism (Oxford: Oxford University Press, 1994), 170.

5. The French of Baudelaire states: 'les mots ressuscitent revêtus de chair et d'os'.

6. Charles Baudelaire, The Poem of Hashish (Sydney: Readhowyouwant, 2006), 65-66.

7. As the title to the collection in English of his writings on Baudelaire emphasises, Charles Baudelaire: A Lyric Poet in the Age of High Capitalism (London: New Left Books, 1973).

8. Kenneth Rexroth, Classics Revisited (1965; New York: New Directions, 1986), 173.

9. Walter Benjamin, 'The Paris of the Second Empire in Baudelaire', in Selected Writings, vol. 4 (Cambridge, MA: Harvard University Press, 2003), 65.

10. Walter Benjamin, 'The Paris of the Second Empire in Baudelaire', in Selected Writings, vol. 4 (Cambridge, MA: Harvard University Press, 2003), 92.

11. T.W. Adorno, Aesthetic Theory (London: Continuum, 2004), 418.

12. This argument is voiced in Dialectic of Enlightenment, first published in 1947, co-authored by T. W. Adorno and Max Horkheimer.

13. Adorno, Aesthetic Theory (London: Continuum, 2004), 319.

14. See Adorno, Aesthetic Theory (London: Continuum, 2004), 68.

15. Walter Benjamin, Gesammelte Schriften, vol. 7.1 (Frankfurt/Main: Suhrkamp, 1992), 110-11.

16. Walter Benjamin, Berlin Childhood around 1900 (Cambridge, MA: Harvard University Press, 2006), 131.

17. Walter Benjamin, Berlin Childhood around 1900, (Cambridge, MA: Harvard University Press, 2006), 131.

18. Paul Wegener, from a lecture given on 24th April 1916, at an Easter Monday conference, and printed in Kai Möller, Paul Wegener (Hamburg: Rowohlt Verlag, 1954). Quoted in Lotte H. Eisner, The Haunted Screen (Berkeley: University of California Press, 1974), 33.

19. Walter Benjamin, 'The Task of the Translator', Selected Writings, vol.1 (Cambridge, MA: Harvard/Belknap Press, 1999), 253-63.

20. Now published, as well as available online, by Openned, 2011.

21. Preface to Lyrical Ballads (1800), The Complete Poetical Works of William Wordsworth, (New York: Houghton, Mifflin \& Company, 1932), 791.

22. See, for example, the trilogy Empire (2000), Multitude (2004) and Commonwealth (2009), as their notion of the common and commons is progressively worked out as a sublation of the private and the public. 